\title{
Metodo mistoak Hezkuntza-ikerkuntzan
}

\author{
Karlos Santiago Etxeberria \\ Hezkuntzarako Ikerkuntza eta Diagnosi Metodoen Saila \\ Hezkuntza, Filosofia eta Antropologia Fakultatea (UPV/EHU) \\ karlos.santiago@ehu.eus \\ Olaia Jimenez Arrieta \\ Humanitate eta Hezkuntza Zientzien Fakultatea \\ Mondragon Unibertsitatea \\ olaia.jimenez@mondragon.edu \\ J.F. Lukas Mujika \\ Hezkuntzarako Ikerkuntza eta Diagnosi Metodoen Saila \\ Hezkuntza, Filosofia eta Antropologia Fakultatea (UPV/EHU) \\ jf.lukas@ehu.eus
}

DOI: http://dx.doi.org/10.1387/tantak.19827

GAKO-HITZAK: Hezkuntza-ikerkuntza, ikerkuntza-paradigmak, osagarritasun metodologikoa, metodo mistoak.

\section{SARRERA}

Metodo kuantitatibo eta kualitatiboen arteko integrazioa ontzat ematen denean, metodo horien zilegitasuna aitortzen da. Era honetan, gizarte gertaerak ikusmolde desberdinetatik ezagutzeak dituen abantailak onesten dira. Orain dela urte batzuk, egileek osatzen zuten ikerketa taldeari hezkuntza-programen ebaluazioa egitea eskatu zitzaien. Horren aurrean izan zuten eztabaidetako bat metodo egokiena aukeratzea izan zen. Ebaluazio horretan planteatu ziren helburuak hartuz, osagarritasun metodologikoaren hautua egin zen, alegia, metodologia kuantitatiboen zein kualitatiboen ekarpenak baliatzea ahalbidetzen duena. Gaur egun, garai batean baino errazago uler daiteke erabaki hau. Orain ez denbora asko, ikerketa metodo bakarreko egoera zen hezkuntza-ikerkuntzarena, berdin kuantitatiboa ala kualitatiboa. Kontua norberak defendatzen zuen metodoa ahalik eta modu zorrotzenean erabiltzea. Gaur egunean onartuta dago modu desberdinetan iker eta ebalua daitekeela. Horren ildotik, batzuek metodo mistoen erabil- 
pena defendatzen dute. Artikulu honen helburua metodo mistoen inguruko ekarpena egitea. Alde batetik gaiaren inguruko hausnarketa teorikoa eskainiz eta bestetik, praktikara eramateko adibide plazaratuz. Azkenik argitu behar da, artikuluan batik bat hezkuntza-ikerkuntzaz aritu arren, hezkuntza-ebaluaziorako baliagarria dela irakur daitekeen guztia.

\section{OSAGARRITASUN METODOLOGIKOA}

Jakina da, nola hezkuntza-ikerkuntzak hala hezkuntza-ebaluazioak beren erronkei aurre egiteko hainbat metodo dituztela. Metodoen berezitasunak eta haien arteko ezberdintasunak ulertzeko, sakonean dauden oinarri teorikoak (hezkuntza-ikerkuntzako paradigmak) ezagutzea ezinbestekoa da.

Osagarritasun metodologikoaren auzia paradigmen eztabaidarekin lotuta dago. Ez da gure asmoa paradigma bakoitzaren ezaugarrietan sakontzea, baizik eta alderdi metodologikoei begiratuz paradigmen arteko eztabaidak hezkuntza-ikerkuntzan duen eragina ikustea.

Paradigmak komunitate zientifiko batek onartutako marko zientifiko zehatz bat ematen digu. Horren ondorioz, paradigma bakoitzak ikerkuntza-praktika zehatzak eskaintzen ditu. Paradigma kopuruei buruz adostasunik ez da egon eta ez dago. Garai batean paradigma kuantitatibo eta kualitatiboaz hitz egiten zen bitartean (Cohen eta Manion, 1990; Cook eta Reichardt, 1986; Lincoln eta Guba, 1985), beste batzuentzat (Bisquerra, 1989; Colás eta Buendía, 1995; De Miguel, 1988; Latorre, 1996) hiru paradigma daude (positibista, interpretaziozkoa, sozio-kritikoa). Noizbait lau eta bost paradigma ere aipatu izan dira.

Ondoko irudian, egun hiru paradigma nagusienen ezaugarri garrantzitsuenak aurkezten dira modu labur batean.

\begin{tabular}{c|c|c}
\hline $\begin{array}{c}\text { Paradigma } \\
\text { positibista }\end{array}$ & $\begin{array}{c}\text { Paradigma } \\
\text { interpretatzailea }\end{array}$ & $\begin{array}{c}\text { Paradigma } \\
\text { kritikoa }\end{array}$ \\
\hline $\begin{array}{c}\text { Kuantitatiboa } \\
\text { Enpiriko-analitikoa } \\
\text { Arrazionalista }\end{array}$ & $\begin{array}{c}\text { Kualitatiboa } \\
\text { Naturalista } \\
\text { Humanista }\end{array}$ & Soziokritikoa \\
\hline $\begin{array}{c}\text { Natura-zientzietako metodo } \\
\text { zientifikoaren aplikazioan } \\
\text { oinarrituta. Bere asmoa da } \\
\text { hezkuntza gertakarien kau- } \\
\text { sazko azalpena ematea. }\end{array}$ & $\begin{array}{l}\text { Bere helburua da hezkun- } \\
\text { tzaren esparruan parte } \\
\text { hartzen duten kideen esa- } \\
\text { nahietan eta intentzioetan } \\
\text { oinarrituz, hezkuntza ger- } \\
\text { takarien ulermena eta in- } \\
\text { terpretazioa egitea. }\end{array}$ & $\begin{array}{l}\text { Bere asmoak gertaka- } \\
\text { rien ulermen soila gaindi- } \\
\text { tzen du, irtenbideak bila- } \\
\text { tuz errealitatea eraldatzeko } \\
\text { hezkuntza praktikaren eten- } \\
\text { gabeko hausnarketa erabiliz } \\
\text { horretarako. }\end{array}$ \\
\hline \multicolumn{2}{c}{ 1. irudia } \\
\hline \multicolumn{3}{c}{ Hezkuntza-ikerkuntzaren paradigmak }
\end{tabular}


Ikerketak burutzeko metodologiari begiratuz gero, kontutan izan gabe zenbat paradigma onartzen ditugun, bi prozedura edo aukeraz hitz egin behar dugu: metodo kuantitatiboak eta kualitatiboak. Metodo kuantitatiboen artean, esperimentalak, korrelaziozkoak eta deskribatzaileak ditugu. Metodo kualitatiboen artean, besteak beste, etnografikoa, kasu-azterketa, lankidetzazko-ikerkuntza eta ikerkuntza esku-hartzailea. Metodo kuantitatibo eta kualitatiboen ezaugarri nagusiak honako irudi honetan ikus daitezke.

\begin{tabular}{|c|c|c|}
\hline & M. Kuantitatiboa & M. Kualitatiboa \\
\hline $\begin{array}{l}\text { Ezaugarri } \\
\text { orokorrak }\end{array}$ & $\begin{array}{l}\text { Egiaztagarria, inferentziala } \\
\text { eta hipotetiko-deduktiboa } \\
\text { Emaitzetara bideratua } \\
\text { Orokorgarria }\end{array}$ & $\begin{array}{l}\text { Arakatzailea, deskribatzailea } \\
\text { eta induktiboa } \\
\text { Prozesuetara bideratua } \\
\text { Ez-orokorgarria }\end{array}$ \\
\hline Diseinua & $\begin{array}{l}\text { Aldez aurretik eta kanpotik } \\
\text { erabat finkatua }\end{array}$ & Irekia eta malgua \\
\hline $\begin{array}{l}\text { Partaideen } \\
\text { aukeraketa }\end{array}$ & $\begin{array}{l}\text { Estatistikako jardunbideak } \\
\text { erabiliz }\end{array}$ & $\begin{array}{l}\text { Subjektuen interes eta beha- } \\
\text { rren arabera zehazten da }\end{array}$ \\
\hline $\begin{array}{l}\text { Datu-bilketarako } \\
\text { teknikak }\end{array}$ & $\begin{array}{l}\text { Tresna baliodun eta fidaga- } \\
\text { rriak: testak, proba objekti- } \\
\text { boak, behaketa sistemati- } \\
\text { koa... }\end{array}$ & $\begin{array}{l}\text { Teknika kualitatiboak: beha- } \\
\text { keta kualitatiboa, elkarrizketa } \\
\text { kualitatiboa, eztabaida-tal- } \\
\text { deak, landa-oharrak, doku- } \\
\text { mentuak, argazkiak, ... }\end{array}$ \\
\hline $\begin{array}{l}\text { Datuen azterketa } \\
\text { Interpretazioa }\end{array}$ & Estatistika teknikak & $\begin{array}{l}\text { Murrizketak, kategorizazioak, } \\
\text { azalpenak, triangulazio }\end{array}$ \\
\hline $\begin{array}{l}\text { Kalitatea } \\
\text { irizpideak }\end{array}$ & $\begin{array}{l}\text { Barne eta kanpo baliotasuna } \\
\text { Fidagarritasuna } \\
\text { Objektibotasuna }\end{array}$ & $\begin{array}{l}\text { Sinesgarritasuna } \\
\text { Transferigarritasuna } \\
\text { Mendekotasuna Berresgarri- } \\
\text { tasuna }\end{array}$ \\
\hline
\end{tabular}

Paradigma bakoitzaren aldekoen eta kontrakoen artean sortutako eztabaidek zenbait jarrera sortu dituzte ikerkuntza-praktikari begiratuz. Laburbilduz honako hauek dira jarrera aipagarriak: 
- Paradigmen arteko gatazka. Paradigmak elkarrezinak dira eta metodoak bateraezinak dira. Horren ondorioz bi jarrera nabarmendu daitezke:

- Metodo bakar baten defentsa eta besteen gaitzespena. Horrela, metodo kuantitatiboei, mekanikoak eta murriztaileak direla edota baloreak eta indibidualtasuna ez dituela kontuan hartzen leporatzen zaie. Metodo kualitatiboei aldiz, prozedura zientifikoei uko egiten dietela, fidagarritasun gutxikoak direla, ikerketak ezin direla errepikatu edota ikertzaileen balioen gainkarga daramatela.

- Beste metodoen onarpena baina osagarri modura, alegia, bigarren mailakotzat joz.

- Batasun epistemologikoa. Paradigmen arteko lehia gainditu behar dela planteatzen da eta kasu bakoitzera hobeto egokitzen den metodoa erabiltzea aholkatzen da (Walker eta Evers, 1997). Metodo mistoak jarrera honen barruan kokatzen dira. Autore batzuek (Mertens, 2005; Teddlie eta Tashakkori, 2009) ikuspegi honi paradigmaren kategoria eman eta «paradigma pragmatikoaz» hitz egiten dute.

Osagarritasun metodologikoaren ideia, metodo mistoena baino zabalagoa da. Hau da, metodo mistoek metodoak integratzen dituzte. Osagarritasun metodologikoak aldiz, metodoen integrazioaz gain, beste metodo batzuen aplikazioa ere onartzen du, nahiz eta azterketa desberdinetan burutu. Nolanahi ere, osagarritasun metodologikoaz hitz egitean, «bateragarritasun eta lankidetza ideiak onartzen ditugu, nolabait, bateraezintasun eta enfrentamendu ideien aurretik». (Lukas eta Santiago, 2016, 51 orr.).

Zer da integrazio metodologikoa? Integrazio metodologikoa kuantitatibo-kualitatibo bitasunarekin amaitzeko modu bat da. Sánchez Gomezek (2015) dioenez, bitasun horrek balizko beste aukera metodologikoak ezkutatzen ditu. Halaber, metodo batek bestearen nagusitasunarekin apurtzeko era bat da. Jada 1986an, Cook eta Reichardt-ek hauxe zioten: «No existe nada, excepto quizás la tradición, que impida al investigador mezclar y acomodar los atributos de los dos paradigmas para lograr la combinación que resulte más adecuada al problema de investigación y a los medios con que se cuenta» (1986, 40 orr.). Bi metodoak bateraezintzat jotzeak bata ala bestea erabiltzea ekartzen du.

Metodoen integrazioa onartzen denean, metodo desberdinen baliotasuna eta zilegitasuna onartzen da. Metodoen integrazioan egindako lehendabizikotako ekarpenak Bericat (1998) soziologoak egin zituen. Autore horrek zioenez, metodologia kuantitatibo eta kualitatiboaren arteko desberdintasunak ezin dira gutxietsi. Baina orain artean egindakoa desberdintasunak puztea izan da, gizarte ikerkuntza eredu baztertzaile gisa aurkeztuz.

Integrazio metodologikoak hauxe esan nahi du: paradigma baten ezaugarri guztiak banaezinak direla ez sinestea eta metodoek paradigma ez- 
berdinetako elementuak dituztela aitortzea. Creswellek (2005) adierazten duen moduan, metodo batzuk lotuagoak daude ikuspegi batekin beste batekin baino. Halere, metodo bat ikuspegi bakar batena dela esatea zerbait irreala da. Creswellen aburuz, metodoen integrazioaren aurkako jarrerak ikuspegi epistemologikoen arteko bateraezintasunean oinarritu dira. Dena den, azken urteetan hainbat autorek jarrera dikotomiko hori okerra dela nabarmendu dute. Esate baterako, edozein erakunde errealitate objektibo bat da, baina errealitate desberdinez osatutako errealitate subjektiboa. Hernández, Fernández eta Baptistari jarraituz, «En la práctica no existen la total objetividad ni la total subjetividad, lo que encontramos es intersubjetivi$d a d »(2011,754$ orr.).

\section{METODO MISTOAK. HISTORIA ETA ESANAHIA}

Ondorengo lerroetan metodo mistoen historiari buruzko zertzelada nagusi batzuk aurkeztuko ditugu.

Nahiz eta horrela ez ezagutu, 60ko hamarkadan kriminologiako lanetan hasi ziren metodo mistoak erabiltzen.

70eko hamarkadaren bukaeran, Jick-ek (1979) diseinu mistoen oinarrizko terminoak sortu zituen. Teknika kuantitatibo eta kualitatiboak erabiliz datuak eskuratzea proposatu zuen eta datuen triangulazioa irudikatu zuen.

80ko hamarkadan ikerkuntza mistoaren zilegitasunari buruzko eztabaida hasi zen. Triangulazioaren kontzeptua, datu kuantitatibo eta kualitatiboen arteko konparaketatik haratago zabaldu zen eta triangulazio desberdinez hitz egiten hasi zen (teoriena, metodoena, ikerlariena, ikuspegiena...).

90eko hamarkadako eztabaida oso gatazkatsua izan zen. Ikuspegi mistoa eremu desberdinetan aplikatu zen (hezkuntzan, komunikazioan, psikologian, medikuntzan eta erizaintzan).

Gure hurbileko testuinguruan, Dendaluce irakaslea aipa dezakegu. «Pluralismo integratzaile» kontzeptua erabili zuen, maila metodologiko eta teknikoetan integrazioa bultzatuz. Autore honen proposamenen artean, «diseinu kuasi-esperimentalen kualitatibizazioa» nabarmendu daiteke (Dendaluce, 1995 eta 1998)

2003. urtean British Educational Research Journal aldizkariak, hezkuntza-ikerkuntzari buruzko ale monografikoan metodo mistoei buruzko 4 artikulu argitaratu zituen. Urte berean, Creswell, Plano Clark, Guttman eta Hanson-ek (2003) diseinu mistoen tipologia bat aurkeztu zuten. Tipologia hau osatzen eta berrikusten joan zen hurrengo urteetan. 2005ean argitaratzen hasi zen Journal of Mixed Methods Research aldizkaria eta «American Educational Research Association» (AERA)-ren barruan gaia lantzeko talde espezifiko bat sortu zen (Punch, 2009). 
Laburbilduz, hauxe esan daiteke: xx. mendea ikuspegi nagusiarekin hasi zen (kuantitatiboa) eta bi oinarrizko ikuspegiekin amaitu zen (kuantitatibo eta kualitatiboa). XXI. mendea hirugarren bide batekin hasi zen, ikusmolde mistoarekin. Hau al da paradigma berria? Paradigma bat gehiago al da?

Osagarritasun metodologikoaren inguruan, esanahi berdina edo oso antzekoa duten kontzeptu desberdin gehiago aurki ditzakegu, hala nola: eredu mistoa, ikuspuntu mistoa, diseinu mistoa, metodo mistoa, prozesu mistoa, metodo anitza, metodo anitzen ikuspuntua... Morse eta Niehaus-ek (2009) bi multzotan biltzen dituzte «osagarritasun metodologikoa» gaiaren pean erabiltzen diren termino edo aldaerak. Hauek dira:

- Metodo mistoa (Mixed method). Hemen, ikerketa bakar batean bi metodo ezberdinak (kuantitatibo eta kualitatiboa) konbinatzen dira. Artikulu honetan hartu dugun ikusmoldea bigarren hau da, alegia, metodo mistoaz hitz egiten dugunean ikerketa-proiektu berean metodo desberdinak erabiltzea.

- Eredu antzeko ikerkuntza (Multiple model research). Kasu honetan, ikerketa-objektu baten gainean 2 ikerketa-proiektu osoak aldi berean erabiltzen dira. Horrek esan nahi du bi ikerketa-proiektu osorik batera burutzen direla (biak kuantitatiboak, biak kualitatiboak). Ikerketa mota honen aldaera Tashakkori eta Teddliek (2010) aipatzen duten «metodo anitzeko ikerkuntza (multiple method research)». Kasu honetan paraleloki doazen proiektuetariko bakoitzak bere metodoa erabiltzen du (batak kuantitatiboa eta besteak kualitatiboa).

Ikerketa-arazo baten aurrean, ikerketa-prozesuan teknika, datu edo prozedura kuantitatibo eta kualitatiboak nahasten direnean, metodo mistoa dela esan dezakegu. Nahasketa hori aldi berean edo une desberdinetan eman daiteke eta bi metodoak garrantzi berekoak edo desberdinekoak izan daitezke.

Datuen bilketa soiletatik baino harago doan prozesua da. Metodo mistoa erabiltzeak berekin dakar logika deduktiboa eta induktiboa nahastu behar izatea (Bergman, 2010). Azterketa baten metodologian ikuspegi kuantitatiboak eta kualitatiboak nahasten dira (Tashakkori eta Teddlie, 2010). Ikuspegi paradigmatikoagoa da. Azken autoreentzat, 3. mugimendu metodologikoa da eta metodo kuantitatibo eta kualitatiboen estatus berbera dute.

Johnson, Onwuegbuzie eta Turnerrentzat (2007) ikerketa mota bat da eta ikerlaria edo ikerketa-taldeak ikusmolde kuantitatibo eta kualitatiboen elementuak konbinatzen ditu (ikuspegiak, datu-bilketa, analisiak, inferentzia teknikak...) ulermena eta berrespena zabaldu eta sakontzeko helburuarekin. 


\section{METODO MISTOEKIKO JARRERAK. ALDEKOAK ETA KONTRAKOAK}

Ikerketa bakar batean ikuspegi kuantitatibo eta kualitatiboak batera erabiltzeko aukeraren aurrean hainbat jarrera agertzen dira. Hernández, Fernández eta Baptistak (2011) lau jarrera desberdintzen dituzte:

- Fundamentalismo metodologikoa. Ikuspegi bat defendatzen du eta bestea arbuiatzen du. Ikertzeko ikuspegi bakarra onartzen du eta metodo mistoa baztertzen du.

- Bereizketa. Estatus berdina eduki dezaketen arren, bi ikuspegiak kontrajarriak dira eta ezin dira nahasi.

- Integrazioa. Bi ikuspegiak maila berean daude eta azterketa batean konbinatzeko aukera onartzen dute.

- Pragmatismoa. Metodo kuantitatibo, kualitatibo eta mistoei estatus berdina ematen diete. Edozein aukera onartzen dute eta ikerketa-arazoaren planteamenduak eta baldintzek iradokitzen dute metodoa.

Mertensek (2005) honako jarrera hauek bereizten ditu:

- Bateraezintasuna: fundamentalismo eta bereizketa.

- Osagarritasuna: integrazioa.

- Pragmatismoa.

Ondoko lerroetan, metodo mistoen abantailak eta eragozpenak aurkezten dira (Castañer, Camerino eta Anguera, 2013; Creswell eta Plano Clark, 2011; Hernández, Fernández eta Baptista, 2011; Johnson eta Christensen, 2014).

\section{Metodoak integratzeko aldeko arrazoiak/abantailak}

- Aztertutako fenomenoaren ikuspegi zehatza eta askotarikoa lortzen da, alegia, holistikoa edo osoagoa. Metodo mistoek bi metodoen indarguneak aprobetxatzea ahalbidetzen dute eta, ondorioz, metodo bakoitzaren hutsuneen konpentsazioa lortzen da. Ez dugu ahaztu behar gizarte eta hezkuntza fenomenoek adierazpen pluralak izaten dituztela.

- Ikerketa-arazoa formulatzen eta argitzen laguntzen du, ikuspegi teoriko desberdinak kontutan hartzen baititu.

- Ikerkuntzak metodologia kuantitatiboaren zuhurtasun formala eta metodologia kualitatiboaren sormena eta malgutasuna konbinatzen ditu.

- Datuen aberastasuna handiagoa da, informazioaren izaera eta iturrien jatorriarekiko mugarik ez dagoelako. Azken finean, metodoen konbinaketak testuinguruko informazioa eta informazio kuantifikagarria sortzen ditu. 
- Errealitate baten ulermena eta azalpen eskaerei egokitzeko malgutasun gehiago. Oso konplexuak diren fenomenoen ulermen hobeagoa lortu daiteke. Esate baterako, bide desberdinetatik emaitza berdinetara iristen bada.

- Ondorioak indartsuagoak dira eta beraz, inferentzia zientifikoei konfiantza eta sendotasun handiagoa eskain dakieke.

- Emaitzak azaltzeko gaitasun handiagoa eta ezusteko emaitzen aurrean, berriz, zalantzaren murrizketa.

- Kontrako entzuleriari emaitzak aurkezteko erabilgarria da integrazioa. (Esate baterako, datu estatistikoak elkarrizketen zatiekin batera aurkeztuz).

- Gisa honetako azterketek inpaktu handiagoa izaten dute gizartean.

\section{Metodo mistoen eragozpenak (erronkak)}

- Metodo mistoek teknika desberdinen ezagutza (kuantitatibo eta kualitatiboak) eskatzen dute eta ez da ohikoa bietan trebakuntza izatea.

- Ikerkuntza mistoak esfortzu handiagoa eskatzen du, bai denbora aldetik eta baita baliabideen aldetik ere.

- Besteak konbentzitzeko beharra sortzen da, askotan, aldaketarako irekitasunik ez delako egoten. Indarrean dauden azturak eta modak gainditzeko zailtasunak izaten dira.

- Metodo mistoen bitartez egindako ikerketak baloratzeko irizpide argiak finkatu behar dira. Gaur egun, ikerketa kuantitatiboak baloratzeko irizpideak oso finkatuta daude, aldiz, ez horrenbeste kualitatiboentzat.

- Bibliografia zientifikoaren berrikuspenaren integrazioa beharrezkoa da. Ikerketa kuantitatiboentzat, berrikuspenak berebiziko garrantzia du ikerketa-arazoa formulatu baino lehen. Ikerketa kualitatiboetan aldiz, garrantzi hori ikerketaren amaieran areagotzen da.

\section{ERABAKI GILTZARRIAK}

Ikerketa bat burutzeko metodo mistoa erabiltzea erabakitzen denean, hainbat alderdi kontutan hartu behar dira. Ondoko lerroetan erabaki horietako batzuk aurkezten ditugu.

- Aldi bakoitzaren (kuantitatibo-kualitatibo) independentzia edota interakzioaren maila zehaztu behar da. Aukera posibleak honako hauek dira:

- Prozedura sekuentzialak: metodo batekin lortutako emaitzetan sakondu beste metodoa erabiliz. 
- Elkarturiko prozedurak edo konbergenteak: bi metodoak aldi berean edo modu bateratuan.

- Konbinazioak: ikerketa berean aurreko biak konbinatzea.

- Ikuspegi kuantitatibo edo kualitatiboaren lehentasuna zehaztu, alegia, nagusitasuna zein metodorena den.

$$
Q L+q t \quad q l+Q T \quad q t+Q L \quad Q T+q l
$$

- Sekuentzialak diren diseinuetan, kuantitatibo edo kualitatiboaren unea zehaztu behar da.

$$
Q L \rightarrow q t \quad q l \rightarrow Q T \quad q t \rightarrow Q L \quad Q T \rightarrow q l
$$

- Azkenik, aldiak noiz eta nola nahasi edo integratu behar diren erabaki behar da (interpretazioan, analisian, datuen bilketan, diseinuan, eredu teorikoa eraikitzerakoan). Flick-ek (2014) ikerkuntza kuantitatibo eta kualitatiboa lotzeko garrantzia azpimarratzen du. Halaber, harreman horiek maila desberdinetan gerta daitezkeela dio, hala nola, datuen konbinazioa, datuen integrazioa, luzerako diseinu integratuak, datu kuantitatiboak kualitatibo bihurtu, datu kualitatiboak kuantitatibo bihurtu, emaitza kualitatibo eta kuantitatiboak lotu, ikerketen triangulazio,...

\section{ZENBAIT PROPOSAMEN}

Nahiz eta oraindik metodo mistoen oinarri filosofiko sendorik eta kontzeptualizazio argirik ez egon, maila metodologikoan eta praktikoan izan dira ekarpen handienak. Ildo honetatik zenbait proposamen aurki ditzakegu bibliografia zientifikoan.

Aipatu behar da tipologiek duten garrantzia ikerlarientzako. Tipologiek erreferentzia puntua ematen dute azterlanak orientatzeko eta, gainera, arloari hizkuntza komuna eskaintzen dio. Azkenik tresna pedagogiko gisa duen balioa ere nabarmendu behar da (Tashakkori eta Teddlie, 2006).

Metodoen integrazioen maila apalenak datuen transformazioan oinarritzen dira. Hona hemen zenbait adibide:

- Datu kualitatiboak kuantifikatu. Informazio kualitatiboa kodetzearen ondotik kalkulu estatistikoak egiten direnean (maiztasunak, portzentajeak,..)

- Datu kuantitatiboak kualifikatu. Analisi faktorialaren bitartez, kualitatiboki aztergai emergenteak sortzen direnean.

- Tresna kuantitatibo bat baliozkotzen denean. 
Ondoko ataletan, hiru sailkapen eskaintzen dira. Sailkapen hauek, literatura zientifikoan topatu daitezkeenen artean garatuenak dira eta gure ustez, hezkuntza-ikerkuntzan azaltzen diren arazoetara erraz egokitu daitezke.

\subsection{Integrazio metodologikoaren oinarrizko estrategiak}

Honako sailkapen hau zenbait ekarpenetan oinarrituz egina da (Bericat, 1998; Greene, Caracelli eta Grahan, 1989; Morgan, 1998). Oinarrizko osagarritasun-estrategia batzuk aurkezten dira, ikerketan edota ebaluazioan erabil daitezkeenak.

Osaketa
(completeness)
Triangelaketa
(convergence)
Konbinazioa
(complementarity)

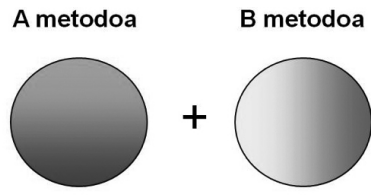

(complementarity)

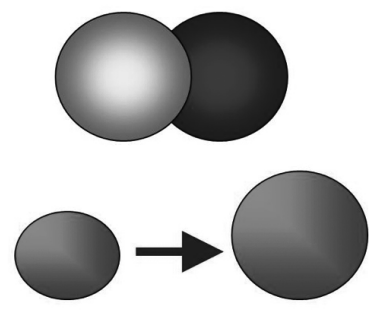

3. irudia

Osagarritasun-estrategiak. Bericat-etik egokitua (1998)

\subsubsection{Osaketa}

Osaketa deritzon estrategiak erantzuten dio aztertu nahi den errealitatearen bi irudi desberdin izateko nahiari. Bata izaera kualitatiboa duen metodotik dator eta bestea izaera kuantitatibo duen metodotik. Kasu hori dugu, esate baterako, ikerketa edo ebaluazio batean bi motatako helburuak planteatzen direnean; helburu batzuk produktu edo inpaktuarekin lotutakoak eta beste batzuk prozesuarekin. Lehen helburu multzorako, metodo kuantitatiboa erabiliko litzateke eta bigarrenerako, kualitatiboa.

Kasu honetan, metodo bakoitzak fenomenoaren alderdi bat argitzen du, metodoen arteko elkargunerik gabe. Metodoen integrazio-maila txikia dela esan daiteke. Azken txostenak, gehienetan, metodo bakoitzeko emaitzak jasotzeko ondo bereizitako bi parte izaten ditu. Integrazioa emaitzen inter- 
pretazioan lortzen da. Osaketa estrategiaren adibide gisa, 2005ean burutu zen ebaluazioa dago (Lukas, Santiago eta Lizasoain, 2005; Lukas, Santiago, Lizasoain eta Joaristi, 2009). Ebaluazio hartan, inpaktuaren ebaluazioa egiteko, diseinu kuantitatiboa «ex post facto» erabili zen.

Hainbat aldagai sozioekonomiko eta ezagutza-mailarekin lotutakoak aztertu ziren. Jasotako datuekin analisi estatistikoak egin ziren. Berriz, egokitasuna eta beharren analisia egiteko, diseinu kualitatiboa erabili zen. Kasu honetan zenbait teknika kualitatibo erabili ziren, hala nola, behaketak, elkarrizketak, eztabaida-taldeak eta dokumentuen analisia. Informazioaren azterketa «analisi ulerkorraren» bitartez egin zen. Ebaluazioaren azken fasean, eztabaida aldian, bi bidetatik jasotako askotariko emaitzak eta aurkikuntzak integratu ziren.

\subsubsection{Triangulazioa}

Triangulazioaren kasuan, metodoek helburu berberari erantzun behar diote ikerketan. Estrategia horretan, errealitatearen ikuspegi osatuagoa lortu nahi da, ez bi begiraden bitartez, baizik eta joera desberdinak erabiliz, errealitatearen alderdi bakar bat aztertzeko. Triangulazioa osagarritasun metodologikoaren oinarria da.

Hemen metodoen triangulazioaz ari gara, baina triangulazioaren erabilera zabala da. Datuak biltzeko tekniken triangulazioa egin daiteke, edo hainbat datu-iturrirena (ikasleak, irakasleak, zuzendaritza, familiak) edo une desberdinena, eta abar. Triangulazioaren garrantzia eztabaidaezina da, «triangulazioak sendotu egiten ditu lortutako emaitzen baliozkotasuna eta sinesgarritasuna, konfiantza handitzen baita irudiaren egiatasunean eta lortutako emaitzetan. Triangulazioaren izaera anitzak berak dakar askotan bera beste osagarritasun-estrategia batzuekin batera gertatzea» (Lukas eta Santiago, 2016: 54 orr.).

Ikus dezagun adibide bat. 2008-2009 ikasturtean Gipuzkoako Ikastolen Elkarteak (GIE) Euskal Herriko Unibertsitateko «Hezkuntzako Ikerkuntza eta Diagnosi Metodoak» saileko hainbat irakasleri IKASYS izeneko programa ebaluatzeko enkargua eman zion (Etxeberria, Lukas eta Santiago, 2011).

Enkarguak bi helburu izan zituen: Alde batetik, aplikatutako programaren eraginari buruzko ziurtasun enpirikoa lortzea. Zehazki esanda, ezagutu nahi zen Euskara, Gaztelania, Ingelesa, Matematika eta Ingurunearen ezaguera-arloekin lotutako edukien eta gaitasunen ikaskuntzan programak izan dezakeen eragina. Gainera, eskolako zenbait zereginetan ikasleek beren burua erregulatzeko duten gaitasuna ere ebaluatu zen, besteak beste, motibazioa, autonomia, kontzentrazioa eta abar. Ikasturte horretan programaren esperimentazioa Euskal Herri osoko 19 ikastolatan egin zen eta $b a$ liokidea ez den kontrol-taldea duen diseinu kuasiesperimentala erabiliz programaren eragina ikertu zen. Gainontzeko gaitasunak eta aldagaiak galdera-sorta eta teknika objektiboen bitartez ebaluatu ziren. 
Enkarguaren bigarren helburua, programa bera eta aplikatzeko prozesua balioestea izan zen. Helburu hau, zuzen-zuzenean, programa eta horren aplikazioa hobetzera zuzendu zen. Programaren osagaiak (hardwarea, softwarea, curriculum-edukiak) eta programaren aplikazioarekin lotutako prozedurak ebaluatu ziren. Behaketan eta elkarrizketetan oinarritutako metodologia kualitatiboa erabili zen. Halaber, ikastola bakoitzean garatutako programari buruz, ikasle, familia, irakasle eta zuzendariek zuten iritzia jaso nahi izan zen.

Ikerketa honek izan zuen berezitasuna hauxe izan zen: hainbat alderdi edo aldagai bi ikuspegietatik aztertu zirela. Hain zuzen ere, motibazio, hardware, software, prestakuntza eta aniztasun alderdiei buruz, bai datu kualitatiboak bai datu kuantitatiboak bildu ziren. Horrek alderdi horiei buruzko informazio osotuagoa eskaini zigun eta, halaber. lorturiko emaitzen baliozkotasuna eta sinesgarritasuna sendotu zituen.

\subsubsection{Konbinazioa}

Konbinazioaren giltzarria hauxe da: ikerketa batean metodo baten ondotik beste metodo bat aplikatzea, aurrekoari segida emanaz. Konbinazio estrategian, emaitzak bateratu baino gehiago, metodoak egoki konbinatu nahi dira, metodo bakoitzaren xedeak desberdinak baitira. Ikerketa batean lagin adierazgarri bati dagozkion emaitzetatik abiatuta emaitza horietan sakontzea nahi izaten da, teknika kualitatiboak erabiliz.

Artikulu honen adibide gisa, 2005-2006 ikasturtean Arartekoak sustatutako ikerketa dugu (Martín, Lukas, Santiago eta Marchesi 2006). Ikerketa honen xedea, Euskadiko Autonomia Erkidegoko Bigarren Hezkuntzako ikastetxeetako bizikidetzaren eta gatazkaren gaineko txostena egitea zen. Azterlan kuantitatiboko helburua, Euskadiko Autonomia Erkidegoko ikastetxeko komunitateko kide ezberdinen iritziak jasotzea izan zen, ikastetxeetako bizikidetzari buruz eta baita bertan jazotzen diren gatazka mota ezberdinen eraginari, horretarako arrazoiei eta ebazpen moduei buruz. Horretarako zoriz aukeratutako 80 ikastetxetako laginean garatu zen ikerketa hainbat galdera-sorta aplikatuz.

Azterlan kualitatiboaren helburua izan zen azterlan honetarako aukeraturiko ikastetxeetako bizikidetza-harremanetan agertzen ziren faktoreak zehaztasun handiagoz ulertzea, batez ere ikasleen arteko harreman sozialei eta haien baloreei zegozkienak. Modu berean, ikasle, irakasle eta familien iritzia ezagutu nahi izan zen ikastetxean garatu ahal izan diren bizikidetzaprogramen inguruan. Azterketa kualitatibo hau garatzeko, hamar ikastetxe aukeratu ziren $80 \mathrm{ko}$ laginetik. Aukeraketa egiteko fase kuantitatiboan lorturiko emaitzak erabili ziren hainbat irizpide kontutan hartuz. Kasu honetan, ikerketaren lehendabiziko zatian ateratako emaitzek guztiz baldintzatu zuten bigarren zatia. 
Ikus daitekeenez, «osaketa» estrategian ez bezala, kasu honetan azterketak ondoz ondokoak dira, ez aldi berekoak. Konbinazioa erabiltzeko beste modu bat dugu, kasu batzuk kualitatiboki sakon aztertu ondoren, orokortzeak egitea: kasu horiek kuantitatiboki ebaluatzeko alderdiei buruzko informazioa eman dute.

\subsection{Metodo mistoen diseinuak}

Johnson eta Christensenek (2014) diseinu mistoen sailkapen bat proposatu zuten. Sailkatzeko bi irizpide erabili zituzten. Alde batetik, zein paradigma edo metodori ematen zaion enfasia eta bestetik zein ordenatan aplikatzen diren diseinuak. Horren ondorioz, 4.irudian ikus daitekeen diseinu sorta gerta daiteke. Sinbologia ulertzeko, ikus dezagun adibide pare bat:

- QUAL + QUAN. Diseinu hau konkurrentea da. Kasu honetan bi metodoak aldi berean aplikatzen dira. Beste alde batetik, ez dago metodo baten lehentasuna. Bi metodoak garrantzi berdinekoak dira.

- quan $\rightarrow$ QUAL. Kasu honetan diseinu sekuentzial baten aurrean gaude, alegia, metodo bat (kualitatiboa) bestearen ondotik (kuantitatiboa) aplikatzen da. Halaber, ikerketaren enfasia metodo kualitatiboari ematen zaio.

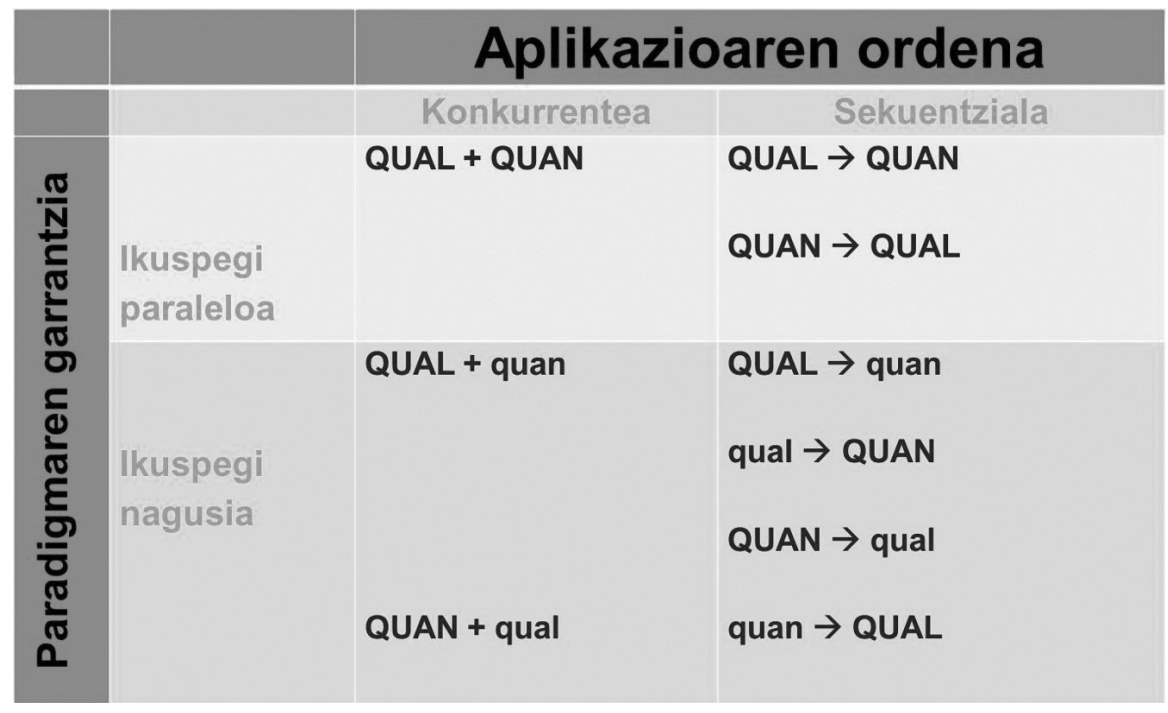

4. irudia

Metodo mistoen diseinuak (Johnson eta Christensen, 2014) 
Johnson eta Christensenen irizpideaz gain, Leech eta Onwegbuziek (2009) hirugarren irizpide bat erabili zuten, konbinazio-maila deitu zutena. Irizpide honen arabera diseinua «ez erabat mistoa» edo «erabat mistoa» izan zitekeen, metodoen nahastea aldi batzuetan edo aldi guztietan ematen den kontuan hartuz.

\subsection{Diseinu mistoak}

Creswell eta Plano Clarkek (2011) metodo mistoen lau diseinu-mota nagusi definitzen dituzte: konbergentea (convergent), esplikaziozkoa (explanatory), esploraziozkoa (exploratory) eta txertatua (embedded). Sailkapena egiteko erabilitako irizpideak honako hauek dira: helburuak, prozedura nagusiak, ohiko aldaerak, indarguneak eta erronkak.

\subsubsection{Diseinu konbergente paraleloa (Convergent parallel design)}

Diseinu honen helburua, bi metodologien indarrak konbinatzea da. Ikerketa hauek fase bakar batean burutzen dira.

Zenbait kasutan ikerketa-arazo bati buruz datu osagarriak lortzeko planteatzen da. Kasu honetan, konbergentzia eta emaitzen berrespena bilatzen da. Beste batzuetan, aldiz, ikerketa berean formulatu daitezkeen helburu desberdinei erantzutea. Kasu honetan, helburu bakoitzarentzat erabakitzen da metodoa.

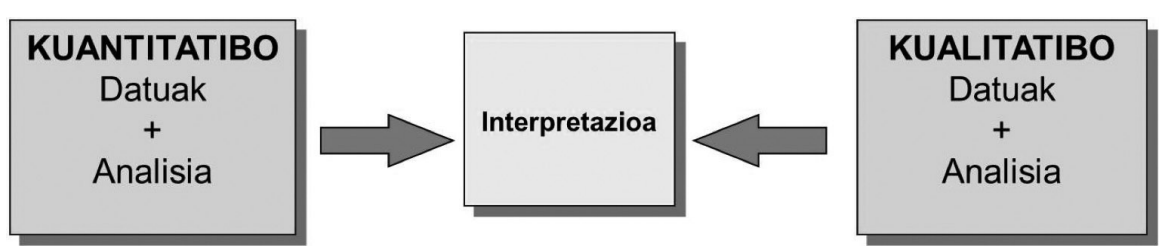

5. irudia

Diseinu konbergente paraleloa

Kuantitatiboen eta kualitatiboen pisua berdina da. Datu kuantitatibo eta kualitatiboak biltzen dira bakoitza bere aldetik, eta batera aztertzen dira. Emaitzen interpretazioan integrazioa bilatzen da (berretsi, konparatu, kontrastatu...).

Diseinu honek baditu bere indarguneak eta erronkak edo ahuleziak. 6.irudian ikus daitezke. 


\begin{tabular}{l|l}
\hline \multicolumn{1}{c|}{ Indarguneak } & \multicolumn{1}{c}{ Erronkak/Ahuleziak } \\
\hline $\begin{array}{l}\text { Ikerlari gehienentzat ezaguna da. } \\
\begin{array}{l}\text { Ondo oinarritutako ondorioak lortzen } \\
\text { dira. }\end{array}\end{array}$ & $\begin{array}{l}\text { Fenomeno baten azterketari ekiteko bi } \\
\text { metodoen ezagutzak behar izaten dira. }\end{array}$ \\
\hline $\begin{array}{l}\text { Datu-bilketa, denbora epe laburrean } \\
\text { egin daiteke. }\end{array}$ & $\begin{array}{l}\text { tako emaitzak konparatzea zaila izan } \\
\text { daiteke. }\end{array}$ \\
\hline $\begin{array}{l}\text { Datu mota bakoitza, bere aldetik jaso } \\
\text { eta azter daiteke. }\end{array}$ & $\begin{array}{l}\text { Emaitzen artean desadostasunak izaten } \\
\text { direnean, kasua ebazteko arazoak sor } \\
\text { daitezke. }\end{array}$ \\
$\begin{array}{l}\text { Taldekako lana ahalbidetu dezake (me- } \\
\text { todologia bakoitzean adituak direnen } \\
\text { artean). }\end{array}$ & $\begin{array}{l}\text { Esperientzia eta esfortzua behar da bi } \\
\text { metodoek pisu berdina izateko. }\end{array}$ \\
\hline \multicolumn{2}{c}{ Diseinu konbergente paraleloaren indarguneak eta ahuleziak }
\end{tabular}

Adibide gisa, imajinatu dezagun irakasleen asebetetzeari buruzko azterketa egin nahi dugula. Lagin bat aukeratu daiteke eta galdera-sorta bat aplikatu. Beste lagin batekin aldi berean, eztabaida taldeak eta banakako elkarrizketak egin daitezke. Bi metodoak zentratu daitezke alderdi berdinetan edo desberdinetan baina, bi kasuetan interpretazioan bat etorriko dira.

Diseinu honen adibidea 5.1. atalean osaketa estrategia azaltzeko aurkeztutakoa da (Lukas, Santiago eta Lizasoain, 2005).

\subsubsection{Esplikazio diseinu sekuentziala (Explanatory Sequential Design)}

Bi etapako diseinua da. Aldi kualitatiboek, lehendabiziko aldi kuantitatiboen emaitza esanguratsu, harrigarri, ezusteko edo apartekoak (outlier) interpretatzen laguntzen du. Batzuetan lehentasuna aldagaien arteko erlazioa azaltzea eta interpretatzea da. Halaber, erabil daiteke lehendabiziko fase kuantitatibo batek azpilaginen aukeraketa zuzentzen duenean, bigarren fase kualitatiboan sakontzen jarraitzeko.

Ikerketaren enfasia alderdi kuantitatiboetan egiten denean $(Q T \rightarrow q l)$, ikerlariak sakonean ikertzeko behar diren datu kualitatiboak identifikatzen ditu diseinu kuantitatiboaren bitartez. Eredu honen izena «Jarraipenaren bitarteko esplikazio eredua» da (Creswell eta Plano Clark, 2011). Egile hauek bigarren eredu edo aldaera bat identifikatzen dute, «Partaideen hautaketaren eredua» izenekoa. Kasu honetan, alderdi kualitatiboek dute lehentasuna $(q t \rightarrow Q L)$ eta sakonagoa izango den azterketa kualitatiboan 
parte hartuko duten pertsonak identifikatzeko eta hautatzeko erabiltzen ikertzaileak. Azken diseinu honen adibide gisa, 5.1.3. puntuan «konbinazioa» estrategia azaltzeko aurkeztu den esperientzia (Martín, Lukas, Santiago eta Marchesi, 2006) kontsultatu daiteke.
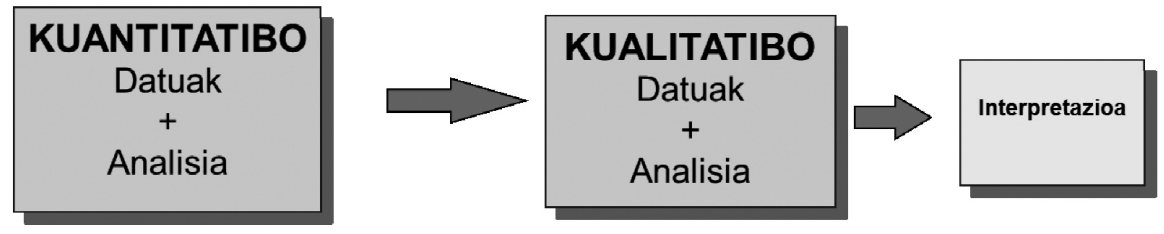

7. irudia

Diseinu esplikatzaile sekuentziala

Koadro honetan, diseinu honek dituen indarguneak eta ahuleziak ikus daitezke.

\begin{tabular}{l} 
Indarguneak \\
\hline Inplementatzeko erraza da aldiro datu \\
mota bakarra biltzen baita.
\end{tabular}

Erronkak/Ahuleziak

Bi aldiak integratzeko denbora asko behar izaten da. Normalki, aldi kualitatiboak denbora gehiago behar izaten du.

mota bakarra biltzen baita.

Bi aldietan pertsona berdinak edo desberdinak erabili behar ote diren erabaki behar da.

Aldi kuantitatiboa bukatu arte ez dira ezagutzen ez aldi kualitatiboaren partai-

Azken txostena bi fasetan idatz daiteke idazketa eta irakurleen ulermena erraztuz.

deak ez eta azalpen gehiago behar duten emaitzak. Hau dela eta, barne-baliotasuna ziurtatzea zaila izan daiteke.

Aldi kualitatiboaren partaideak hautatzeko irizpideak zehazteko beharra.

\section{8. irudia}

Diseinu esplikatzaile sekuentzialaren indarguneak eta ahuleziak

\subsubsection{Esplorazio diseinu sekuentziala / (Exploratory Sequential Design)}

Diseinu hau, aurrekoa bezala, Bericaten «konbinazioa» diseinuarekin bat dator (Bericat, 1998). Oso egokia da datuak biltzeko tresna berri bat eraiki nahi denean edota aldagai garrantzitsuenak identifikatu nahi direnean, gero kuantitatiboki aztertzeko (Castañer, Camerino eta Anguera, 
2013). Era berean, erabilgarria izan daiteke emaitzak talde desberdinetara orokortu nahi direnean.

Diseinu honen hipotesia zera da: esplorazio kualitatiboa beharrezkoa dela azterketa kuantitatiboa egiteko. Esplorazio hori egin gabe, azterketa kuantitatiboa desegokia, ezinezkoa edota alferrikakoa izan daitekeela uste izaten da.

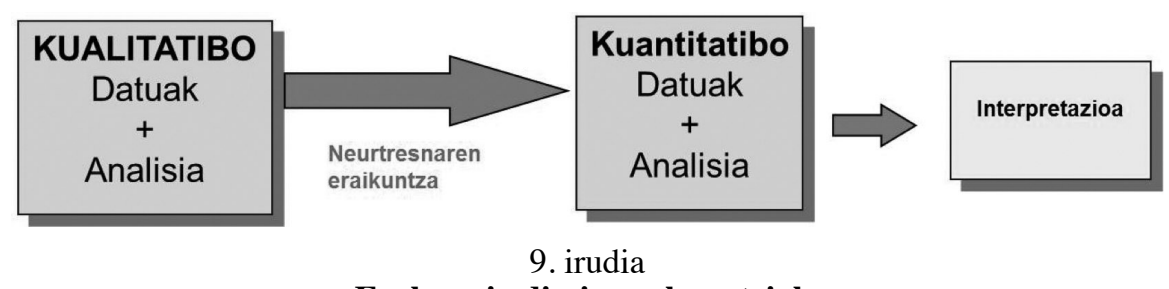

Esplorazio diseinu sekuentziala

Bi etapako diseinua da. Bertan lehendabiziko etapako aurkikuntzek bigarren etaparen garapenean laguntzen dute. Nahiz eta, ikerketaren helburuari begiratuta, enfasia bigarren aldian izan, datu kualitatiboen pisua oso handia da gehienetan. Ondoko koadroan diseinu-mota honen indarguneak eta ahuleziak beha daitezke:

\begin{tabular}{l|l}
\hline \multicolumn{1}{c|}{ Indarguneak } & \multicolumn{1}{c}{ Erronkak/Ahuleziak } \\
\hline $\begin{array}{l}\text { Aldiak argi banatuta daudenez, deskri- } \\
\text { batzeko, aplikatzeko eta dibulgatzeko } \\
\text { diseinu erraza da. }\end{array}$ & $\begin{array}{l}\text { Nahiko denbora behar da praktikara era- } \\
\text { mateko. }\end{array}$ \\
\hline $\begin{array}{l}\text { Osagai kuantitatiboa sartzeak errazten } \\
\text { du kualitatiboaren onarpena metodo } \\
\text { kuantitatiboen defendatzaileen aldetik. }\end{array}$ & $\begin{array}{l}\text { Aldi kualitatiboaren prozedurak aldez } \\
\text { aurretik zehaztea zaila da. }\end{array}$ \\
\hline & $\begin{array}{l}\text { Bai aldi kualitatibo zein kuantitatiboan } \\
\text { aztertu behar da pertsona berberek balio } \\
\text { ote duten parte-hartzaile gisa }\end{array}$ \\
\cline { 2 - 2 } $\begin{array}{l}\text { Fase anitzeko azterketetan erraz aplika } \\
\text { daiteke. }\end{array}$ & $\begin{array}{l}\text { Tresna kuantitatiboa eraikitzeko, aldi } \\
\text { kualitatiboko zein datu erabili behar di- } \\
\text { ren erabaki behar da. Datu horiek nola } \\
\text { erabili neurri kuantitatiboak sortzeko } \\
\text { baita ere. }\end{array}$ \\
\hline
\end{tabular}

10. irudia

Esplorazio diseinu sekuentzialaren indarguneak eta ahuleziak

TANTAK, 30 (1), 2018, 87-111 orr. 
2013-2014 ikasturtean, EHUko irakasleen arloko errektoreordetzak, Irakasleen Irakas-Jardueraz Ikasleek Duten Iritzien Galdetegia Goi Mailako Hezkuntzako Europar Esparrura egokitzeko asmoz, ikerketa-lan bat sustatu zuen. Ikerketa-lan honek bi zati nagusi izan zituen, kualitatiboa eta kuantitatiboa.

Lehendabiziko aldian, beste unibertsitateetan erabilitako galdetegien edukien azterketaren bitartez eta hainbat talde-eztabaidaren bitartez etorkizuneko galdetegiaren eredu teorikoa eta galdetegi-pilotua eraiki zen. Eztabaida-talde horietan, EHUko eta kanpoko aditu, irakasle, ikasle eta SED/ IEZ-eko zuzendaritza eta teknikoek parte hartu zuten.

Bigarren aldian, EHUko ikaslez osatutako lagin bati galdetegiaren proba pilotua aplikatu zitzaion. Proba horri zegozkion analisi estatistikoak egin ziren eta ondorioz behin betiko galdetegiaren proposamena egin zen. Ikerketa lan honi buruz informazio gehiago nahi izanez gero, honako erreferentzia hau kontsulta daiteke: Lukas, Santiago, Etxeberria eta Lizasoain, 2014.

\subsubsection{Diseinu txertatua / (Embedded Design)}

Bericaten «triangulazioa» estrategiarekin bat dator. Azterketa nagusiari laguntza emateko beste metodo bat erabiltzen da, baina bigarren mailako gisa. Ondoko irudian diseinu honen eskema orokorra beha daiteke. Ikus daitekeenez, ikerketa kuantitatiboa nagusia denean azterlan kualitatiboa txertatzen edo tartekatzen da. Alderantziz ere izan daiteke, alegia, metodo kualitatiboa erabiltzen duen ikerketa baten barruan, zati kuantitatiboa sartzea. Ondorengo interpretazioan jasotako datu mota eta analisi guztiak integratzen dira.

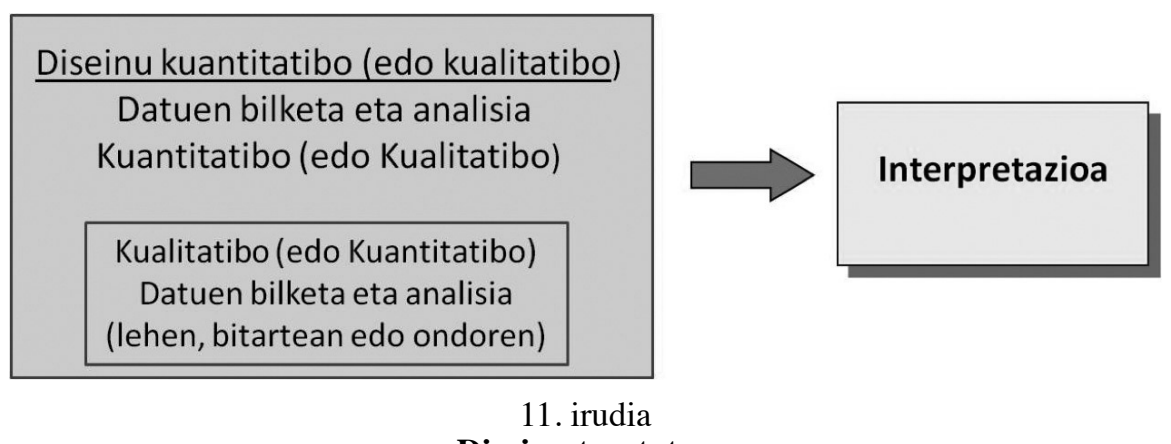

Diseinu txertatua

Kasu honetan hauxe uste da: izaera deserdineko datuak eskatzen dituzten ikerketa galdera batzuk planteatu direla eta ondorioz, metodo bakar bateko datuak ez direla nahikoak. 


\begin{tabular}{|c|c|}
\hline Indarguneak & Erronkak/Ahuleziak \\
\hline \multirow{2}{*}{$\begin{array}{l}\text { Datu kuantitatibo eta kualitatibo ugari } \\
\text { biltzeko denbora edo baliabide nahiko- } \\
\text { rik ez dagoenean erabil daiteke. }\end{array}$} & $\begin{array}{l}\text { Ikerketa kuantitatibo baten barruan } \\
\text { datu kualitatiboen bilketaren helburua } \\
\text { zehaztu behar da (edo alderantziz). }\end{array}$ \\
\hline & $\begin{array}{l}\text { Ikerketa galderak desberdinak dire- } \\
\text { nean, emaitzak integratzea zaila izan } \\
\text { daiteke. }\end{array}$ \\
\hline \multirow{2}{*}{$\begin{array}{l}\text { Logistikoki erabilgarriagoa metodo ba- } \\
\text { tek beste batek baino datu gutxiago } \\
\text { behar izaten duelako. }\end{array}$} & $\begin{array}{l}\text { Diseinu kualitatibo baten barruan datu } \\
\text { kuantitatiboak gehitzen dituzten adibi- } \\
\text { deak topatzea zaila da. }\end{array}$ \\
\hline & $\begin{array}{l}\text { Diseinu esperimentalen kasuan, zein es- } \\
\text { ku-hartzeren unean (aurretik, bitartean, } \\
\text { ondotik) jaso behar diren datu kualitati- } \\
\text { boak erabaki behar da. }\end{array}$ \\
\hline
\end{tabular}

12. irudia

Diseinu txertatuaren indarguneak eta ahuleziak

Ikus dezagun adibide pare bat:
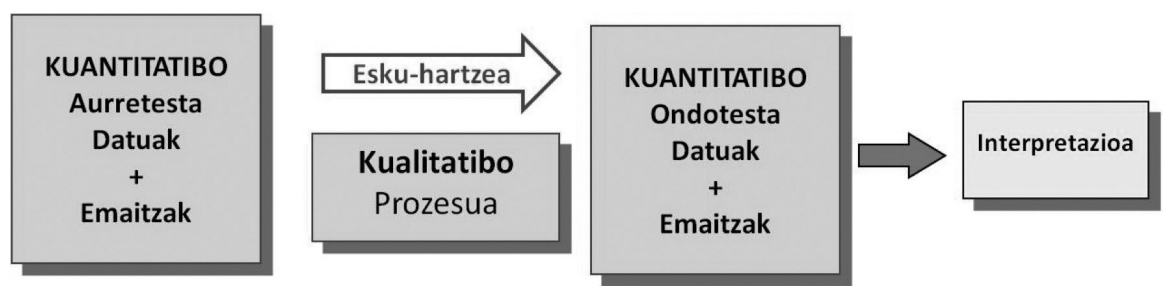

13. irudia

Diseinu txertatua. Adibide 1

Diseinu kuantitatibo baten barruan, esperimentala kasu honetan, osagai kualitatiboa txertatzen da. Hori da aurreko irudiak adierazten duena. 5.1.2. puntuan triangulazioa estrategia azaltzeko aurkeztu den esperientzia diseinu honen adibide da (Etxeberria, Lukas, eta Santiago, 2011). Kasu honetan osagai kualitatiboa tartean txertatzen da esku-hartze prozesua aztertzeko asmoz. Beste kasu batzuetan, aurretik txerta daiteke (esku-hartzea diseinatzeko asmoz) edo ondotik (esperimentuaren emaitzen jarraipena egiteko, alderdi edo aldagairen batean sakontzeko...) 


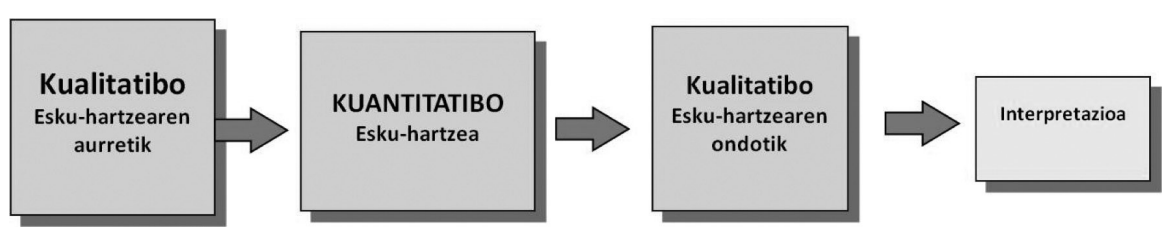

14. irudia

Diseinu txertatua. Adibide 2

Kasu honetan, diseinu kualitatibo bati osagai kuantitatiboa gehitzen zaio. Hasierako diseinu kualitatiboaren helburua, ondorengo esku-hartzea diseinatzea izan daiteke. Bukaerakoa aldiz, esku-hartzearen inpaktuari buruzko informazioa sakontzea.

\section{METODO MISTOEN KALITATE-IRIZPIDEAK}

Metodo mistoak aplikatzeko eragozpenez hitz egitean aipatu da eragozpen horietako bat ikerketak baloratzeko bi metodologiek irizpide desbedinak dituztela. Gainera, metodo kuantitatiboentzat irizpideak oso finkatuta daude, kualitatiboentzat, berriz, ez horrenbeste.

Kalitate-irizpideak ikerketa baten baliotasuna eta sinesgarritasuna bermatzen duten prozedurak dira. Gorard eta Taylorrentzat (2004), ikertzailearen lehendabiziko konpromisoa ikerketaren kalitatea da. Kalitate hori ikerketaren emaitzetan eta aurkikuntzetan dagoen konfiantza-maila da. Lortutako emaitzen egiatasuna justifikatzeko, zilegitasun-maila ematen duten irizpide eta estrategia desberdinak daude. Jakina denez, metodo kuantitatiboetako irizpideak barne-baliotasuna, kanpo-baliotasuna, fidagarritasuna eta objektibotasuna dira. Berriz, metodo kualitatiboetan, ordezko kalitate-irizpide bezala, sinesgarritasuna, transferigarritasuna, sendotasuna eta berresgarritasuna sortu ziren.

Metodo mistoen kalitate-irizpideei dagokionez, garatu diren lehendabiziko soluzioak metodo bakoitzaren irizpideak aplikatzearen bidetik joan dira. Dena den, berezko baliozkotasun-sistema bat sortzea erronka handienetakoa izan da eta da. Gaur egun ez daude ordezko irizpide adosturik metodo mistoentzat. Gai hau gogoeta eta garapen prozesuan dago.

Tashakkori eta Teddliek (2008) inferentziaren kalitatea (inference quality) terminoa proposatu dute. Termino hau diseinuaren sendotasuna eta interpretazioaren zorroztasunari dagokie.

Johnson eta Christensenek (2014) «legitimazioa» (legitimation) proposatzen dute ordezko irizpide gisa eta irizpide hau prozesuaren une guztietara zabaltzea gomendatzen dute. Sandin (2003) bat dator irizpide honekin eta metodo kualitatiboekin gertatu den bezala, metodo mistoen borroka 
nagusienetakoa bere legitimazioaren onarpena izan dela dio. Kontua hauxe da: nola lortu legitimazio zientifikoa? Johnson eta Christensenek diotenez, «legitimazio zientifikoa» lor daiteke aukera baten ahuleziak bestearen indarguneekin konpentsatzen direnean eta ikuspegi bakoitzaren berezko irizpideak errespetatzen direnean (2014). Bericatentzat (1998) legitimazioa, bi metodologiek (kuantitatiboak zein kualitatiboak) gertaera bat antzemateko erakusten duten gaitasunaren mendean dago.

Beste alde batetik, Hernandez, Fernandez eta Baptistak (2011) metodo mistoa aplikatzerakoan kontuan hartu beharko genituzkeen irizpide batzuk planteatu dituzte:

- Metodo bakoitzaren erabilpenaren justifikazioa.

- Ikuspegi bakoitzeko metodoaren zorroztasuna.

- Ikerketaren arazoarekiko metodo bakoitzaren egokitzapena.

- Ikuspegi baten nagusitasunaren justifikazioa.

- Jasotako datuekiko ikuspegiaren koherentzia.

- Metodo bakoitzaren mugen onarpena.

- Metodo desberdinen bitartez lortutako adostasun eta diferentzien azalpena. Halaber desadostasunak ebazteko eraren azalpena.

\section{KONKLUSIOAK}

Lehenik eta behin esan behar da metodo mistoen ikuspegia, eraikitze eta sendotze prozesuan dagoela oraindik. Hala ere, metodoen arteko nagusitasunak parekatzeko aukera zabalik dago. Ikertzailearen lehen erronka metodo mistoak erabili behar dituenean, zorroztasunez diseinu egokiena zein den erabakitzea da. Halaber, bigarren erronka hauxe da: estatus zientifiko eta metodo mistoen oinarri epistemologikoen barruan, baliotasuna lortzeko diseinuak zein irizpide bete behar dituen zehaztea (Díaz López, 2014).

Beste alde batetik, Pérez Justek (2014), metodo mistoek HezkuntzaEbaluazioari egindako ekarpenak goraipatu ditu; bi ikuskeretatik datozen oinarri eta teknikekin lortu daitezkeen balorazioak sendoagoak izango direla ikuskera bakar batetik lortutakoak baino aipatuz. Era berean, egile berak dio, ebaluazioaren objektu eta prozesuaren izaera berak, bi dimentsioak (kuantitatiboa eta kualitatiboa) onartzen dituen trataera eskatzen duela.

Kuantitatiboaren edo kualitatiboaren artean erabakia hartu behar denean, irizpide garrantzitsu bat izaten da ikerketa edo ebaluazioren helburuari egokien erantzuten diona aukeratzea. Metodo mistoen artean zein hautatu planteatzen denean, irizpide hori kontutan hartzea ezinbestekoa da. Ildo honetatik, ikerketa eta ebaluazio batzuei hobeto egokitzen zaizkie nagusitasun kuantitatiboa duten diseinuak, adibidez, pertsona askori dagokien programa bat ebaluatu nahi denean. Beste kasuetan, berriz, nagu- 
sitasun kualitatiboa dutenak egokiagoak dira; adibidez, irakaskuntzaren kalitatea hobetzeko programa bat ebaluatu nahi dugunean.

Diseinu mistoa aukeratzeko, edo hobeto esanda nagusitasuna zein metodoari eman erabakitzeko, aurrekoa bezain arrazionalak ez diren beste irizpide batzuk honako hauek izan daitezke: ikertzaileak zein metodotan duen esperientzia gehiago, erabiltzaile edota azterketaren irakurleak, formakuntza, ikertzailearen ustez hobekien egokitzen den ikusmoldea, finantziazioa, baliabideak, ingurukoen tradizioa, e.a. Dena den, hezkuntzaikerkuntzan fenomeno konplexu eta dimentsio anitzekoak aztergai izanik, ikuspegi holistikoa eta ulermen sakonagoa lortzeko metodoak lehenestea funtsezkoa da. Bide honetatik joz gero hezkuntzaren kalitatea hobetzeko ekarpenak esanguratsuak izan daitezkeelako.

Nahiz eta gai hau oso eztabaidagarria izan gaur egun, oinarrizko hiru printzipioak onartuak direla esan daiteke. Alde batetik, metodo mistoek ez dituztela paradigma kuantitatibo eta kualitatiboa ordezkatzen, baizik eta elkarrekin bizi direla. Bestetik, metodo mistoen xedea bi metodoen indarguneak batuz eta indartuz bakoitzaren ahultasunak murrizten direla. Azkenik, ikerkuntzaren edo ebaluazio-arazoaren ulermena lortzeko, paradigma bakar batek eskaintzen duena baino aukera hobea eskaintzen dutela metodo mistoek.

\begin{abstract}
This article sets out to provide a general review of the basic principles of what is known as «methodological complementarity» in education research. Firstly, it addresses the context in which mixed methods have emerged to then go on to review some of the definitions. After reflecting on the advantages and limitations of these methods, several designs of mixed methods with examples drawn from education research and assessment are presented. The article concludes with an exposition of the discussion about the quality of the research conducted with a mixed method.
\end{abstract}

Keywords: Educational research, research paradigms, methodological complementarity, mixed methods.

Este artículo ofrece una revisión general de los principios básicos de la denominada «complementariedad metodológica» en la inves- 
tigación educativa. En primer lugar se expone el contexto en el que han surgido los métodos mixtos para revisar a continuación algunas de las definiciones. Tras hacer una reflexión acerca de las ventajas y limitaciones de estos métodos se presentan diferentes diseños de métodos mixtos ilustrados con ejemplos tomados de la investigación y evaluación educativas. Finaliza el artículo con una exposición de la discusión acerca de la calidad de la investigación realizada con un método mixto.

Palabras clave: investigación educativa, paradigmas de investigación, complementariedad metodológica, métodos mixtos.

Cet article propose une relecture générale des principes de base de ce qu'on appelle la "complémentarité méthodologique» dans le cadre de la recherche en éducation. Dans un premier temps, sera exposé le contexte au sein duquel sont apparues les méthodes mixtes afin de réviser ensuite quelques définitions. Après une réflexion conduite autour des avantages et limites de ces méthodes, sont présentées différentes méthodes mixtes élaborées et illustrées par des exemples empruntés à la recherche et l'évaluation éducatives. L'article se termine par une présentation des échanges menés sur la qualité de la recherche conduite selon une méthode mixte.

Mots-clé: recherche en éducation, paradigmes de la recherche, complémentarité méthodologique, méthodes mixtes.

\section{ERREFERENTZIA BIBLIOGRAFIKOAK}

Bergman, M. M. (2010). On concepts and paradigms in mixed methods research. Journal of Mixed Methods Research, 4(3), 171-175. DOI:10.1177/1558689810376950

Bericat, E. (1998). La integración de los métodos cuantitativo y cualitativo en la investigación social. Significado y medida. Bartzelona: Ariel.

Bisquerra, R. (1989). Métodos de investigación educativa.Una guía práctica. Bartzelona: CEAC.

Castañer, M., Camerino, O. eta Anguera, M.T. (2013). Métodos mixtos en la investigación de las ciencias de la actividad física y el deporte. Apunts, Educación Física y Deportes, 112, 31-36. DOI: http://dx.doi.org/10.5672/ apunts.2014-0983.es.(2013/2).112.01.

Cohen, L. eta Manion, L. (1990). Métodos de investigación educativa. Madril: La Muralla.

Colás, M.P. \& Buendía, L. (1995). Hezkuntzaren Ikerkuntza. Leioa: EHU. 
Cook, T. eta Reichardt, C. (1986). Métodos cualitativos y cuantitativos en investigación evaluativa. Madril: Morata.

Creswell, J. W., Plano Clark, V. L., Gutmann, M., eta Hanson, W. (2003). Advanced mixed methods research designs. In A. Tashakkori eta C. Teddlie (Arg.), Handbook of mixed methods in social \& behavioral research (209-240 orr.). Thousand Oaks, CA: Sage.

Cresswell, J.W. (2005). Educational research: planning, conducting and evaluationg Quantitative and Qualitative Research. Upper Saddle River, N.J: Merrill.

Creswell, J.W. eta Plano Clark, V.L. (2011) Designing and conducting Mixed Methods Research. London: SAGE.

De Miguel, M. (1988). Paradigmas de la investigación educativa española. In I. Dendaluce (Arg.), Aspecto metodológicos de la investigación educativa (60-77 orr.) Madril: Narcea.

Dendaluce, I. (1995). Avances en los métodos de investigación educartiva en la intervención psicopedágogica. Revista de Investigación Educativa, 26, 9-32.

Dendaluce, I, (1998). Algunos retos metodológicos. Revista de Investigación Educativa, 16, 7-24.

Díaz López, S.M. (2014). Los Métodos Mixtos de Investigación: Presupuestos generales y Aportes a la Evaluación Educativa. Revista portuguesa de Pedagogía, 48(1), 7-23. file:///C:/Users/plpsaetc/Downloads/2222-1-7211-1-1020150414\%20(1).pdf. DOI: 10.14195/1647-8614_48-1_1

Etxeberria, J., Lukas, J.F., eta Santiago, K. ( 2011). Computer-based learning: Evaluation of the IKASYS Project. Revista de Psicodidáctica, 16(2), 311-329.

Flick, U. (2014). La gestión de la calidad de la investigación cualitativa. Madril: Morata.

Gorard, S. eta Taylor, Ch. (2004). Combined methods in educational and social research. Backshire (UK): Open Unibersity Press.

Greene, J.C., Caracelli, V.J. eta Graham, W.F. (1989). Toward a conceptual framework for mixed-method evaluation designs. Educational Evaluation and Policy Analysis, 255-274

Hernández, S, R., Fernández, C. C., eta Baptista, L. P. (2011). Metodología de la investigación (4. arg.). México: McGraw-Hill.

Jick, T. D. (1979). Mixing qualitative and quantitative methods: Triangulation in action. Administrative Science Quarterly, 24, 602-611.

Johnson, R.B., Onwuegbuzie, A.J. eta Turner, L. (2007). Toward a definition of mixed methods research. Journal of Mixed Methods Research, 1, 112-133.

Johnson, R.B. eta Christensen, L. (2014). Educational Research. Quantitative, Qualitative, and Mixed Approaches. Thousand Oaks, CA: Sage.

Latorre, A., del Rincón, D. \& Arnal, J. (1996). Bases metodológicas de la investigación educativa. Bartzelona: GR92.

Leech, N.L. eta Onwuegbuzie, A.J. (2009). A typology of mixed methods research design. Quality and quantity, 43(2), 265-275.

Lincoln, Y.S. eta Guba, F.G. (1985). Naturalistic Inquiry. Beverly Hills, CA: SAGE.

Lukas, J.F., Santiago, K. eta Lizasoain, L. (2005). Vitoria-Gasteiz como ciudad educadora: Evaluación de los programas del Departamento Municipal de Educación. http://www.sc.ehu.es/plwlumuj/ebaluazioa_pedagogia/praktikak/ INFORME-vitoria.pdf 
Lukas, J. F., Santiago, K., Lizasoain, L. eta Joaristi, L. (2009). Evaluación del impacto y pertinencia de programas educativos municipales. Revista Española de Pedagogía, 57(243), 337-354.

Lukas, J.F., Santiago, K., Etxeberria, J. y Lizasoain, L. (2014). Adaptación al Espacio Europeo de Educación Superior de un cuestionario de opinión del alumnado sobre la docencia de su profesorado. RELIEVE. 20(1). DOI: 10.7203/ relieve.20.1.3812.

Lukas, J.F. eta Santiago, K. (2016). Hezkuntza-Ebaluazioa. Bilbo: Euskal Herriko Unibertsitateko Argitalpen Zerbitzua.

Martín, E., Lukas, J .F. , Santiago, K. eta Marchesi, A. (2006). Convivencia y Conflictos en los Centros Educativos. Vitoria-Gasteiz: Ararteko. http://www. ararteko.net/RecursosWeb/DOCUMENTOS/1/1_244_3.pdf

Mertens, D. (2005). Research Methods in Education and Psychology: Integrating Diversity with Quantitative and Qualitative Approaches. Thousand Oaks, CA: Sage.

Morgan, D. (1998). Practical strategies for combining qualitative and quantitative methods: Applications to health research. Qualitative Health Research, 8 , 362-376.

Morse, J. eta Niehaus, L. (2009). Mixed method design. Principles and procedures. Walnut Cree CA: Left Coast Press.

Pérez Juste, R. (2014). Evaluación de programas educativos (2. arg.). Madril: La Muralla.

Punch, K.F. (2009). Introduction to Research Methods in Education. London: SAGE.

Sánchez Gómez, M.C. (2015). La dicotomía cualitativo-cuantitativo: posibilidades de integración y diseños mixtos. Campo Abierto, Vol. Monográfico, 11-30

Sandín, M.P. (2003). Investigación cualitativa en Educación. Fundamentos y tradiciones . Madrid: McGraw Hill.

Tashakkori, A., eta Teddlie, C. (2006). A General Typology of Research Designs Featuring Mixed Method. Research in the schools, 13(1), 12-28. Consultado en: http://www.msera.org

Tashakkori, A., eta Teddlie, C. (2008). Quality of inferences in Mixed Methods Research: Calling for an integrative framework. In M. Bergman (Arg.), Advances in Mixed Methods Research: Theories and Applications (101-119 orr.). California: Sage Publication, Inc.

Tashakkori, A. eta Teddlie, Ch. (Eds.) (2010). The SAGE Handbook of Mixed Methods in Social \& Behavioral Research. Second Edition. London: SAGE.

Teddlie, Ch. eta Tashakkori, A. (2009). Foundations of Mixed Mhetods Research. Integrating Quantitative and Qualitative. Approaches in the Social and Behavioral Sciences. London: SAGE

Walker, J. C. eta Evers, C. W. (1997): «Research in education: Epistemological issues», in J. P. Keeves (Arg.), Educational research, methodology, and measurement: An international handbook, Oxford, Pergamon Press, 22-31. orr. 